\title{
LIME APPLICATION METHODS, WATER AND BOTTOM SOIL ACIDITY IN FRESH WATER FISH PONDS
}

\author{
Julio Ferraz de Queiroz ${ }^{1 *}$; Gilberto Nicolella ${ }^{1}$; Charles Wesley Wood ${ }^{2}$; Claude Elson Boyd ${ }^{3}$ \\ ${ }^{1}$ Embrapa Meio Ambiente - Rod. SP 340 km 127,5, C.P. 69 - 13820-000 - Bairro Tanquinho Velho - Jaguariúna, \\ SP - Brasil. \\ ${ }_{3}^{2} A U$ - Department of Agronomy and Soils, Auburn University, Alabama 36849, USA. \\ ${ }^{3} A U$ - Department of Fisheries and Allied Aquacultures, Auburn University. \\ *Corresponding author<jqueiroz@cnpma.embrapa.br>
}

\begin{abstract}
Although some methods for determining lime requirement of pond soils are available and commonly used, there is still no consensus on whether it is more effective to apply liming materials to the bottoms of empty ponds or to wait and apply them over the water surface after ponds are filled. There is also little information on how deep lime reacts in pond sediment over time, and whether the depth of reaction is different when liming materials are applied to the water or to the soil. Therefore, three techniques for treating fish ponds with agricultural limestone were evaluated in ponds with clayey soils at a commercial fish farm. Amounts of agricultural limestone equal to the lime requirement of bottom soils were applied to each of three ponds by: direct application over the pond water surface; spread uniformly over the bottom of the empty pond; spread uniformly over the bottom of the empty pond followed by tilling of the bottom. Effectiveness of agricultural limestone applications did not differ among treatment methods. Agricultural limestone also reacted quickly to increase total alkalinity and total hardness of pond water to acceptable concentrations within 2 weeks after application. The reaction of lime to increase soil $\mathrm{pH}$ was essentially complete after one to two months, and lime had no effect below a soil depth of $8 \mathrm{~cm}$. Tilling of pond bottoms to incorporate liming materials is unnecessary, and tilling consumes time and is an expensive practice; filled ponds can be limed effectively.
\end{abstract}

Key words: liming, total alkalinity, total hardness, sediments

\section{MÉTODOS DE CALAGEM, ACIDEZ DA ÁGUA E DO SEDIMENTO DO FUNDO DE VIVEIROS DE PISCICULTURA}

\begin{abstract}
RESUMO: Alguns métodos para determinar a quantidade de calcário necessária para corrigir a acidez do fundo dos viveiros de piscicultura estão disponíveis e rotineiramente em uso, mas ainda não existe um consenso se é mais eficiente fazer a aplicação diretamente no fundo ou sobre a superfície da água após o abastecimento dos viveiros. Além disso, existem poucas informações disponíveis sobre até que profundidade o calcário reage com o sedimento do fundo ao longo do tempo, e se a profundidade na qual ocorrem as reações é diferente quando o calcário é aplicado sobre a superfície da água ou sobre o solo. Dessa forma, três técnicas para calagem foram avaliadas em viveiros com solo argiloso em uma piscicultura comercial de acordo com os seguintes métodos: aplicação direta sobre a superfície da água do viveiro, distribuição uniforme sobre o fundo do viveiro vazio, distribuição uniforme sobre o fundo do viveiro vazio seguida da aragem. A eficácia da aplicação do calcário agrícola não diferiu entre os métodos de tratamento. O calcário agrícola reagiu rapidamente para aumentar a alcalinidade e a dureza total da água dos viveiros para concentrações aceitáveis após duas semanas. $\mathrm{O}$ aumento do $\mathrm{pH}$ do sedimento se completou essencialmente após um a dois meses, e o calcário agrícola não teve efeito sobre as camadas de sedimento abaixo de $8 \mathrm{~cm}$. A aração do fundo dos viveiros para incorporação de materiais é desnecessária, consome tempo e é dispendiosa; a calagem pode ser feita de forma eficaz em viveiros cheios.
\end{abstract}

Palavras-chave: calcário, alcalinidade total, dureza total, sedimentos

\section{INTRODUCTION}

Acidic bottom soil is a common problem in pond aquaculture, and fish farmers often apply agricultural limestone to ponds as a remedy. Aquaculture ponds are usually limed after draining for harvest and before refilling for the next crop (Boyd \& Tucker, 1998). However, sportfish ponds are usually not drained for liming, and agricultural limestone is spread over the water surface from a boat (Boyd, 1982).

The objective of liming is to neutralize acidity in the upper layer of bottom soil and to increase concentrations of total alkalinity and total hardness in the water (Thomaston \& Zeller, 1961). Several studies have shown 
positive responses in phytoplankton productivity and fish production following liming of acidic ponds, and methods for determining the lime requirements of bottom soils have been developed (Boyd, 1995). Nevertheless, liming often is applied to ponds indiscriminately, with no concern for bottom soil $\mathrm{pH}$ or total alkalinity and total hardness concentrations. It is doubtful that liming has a large influence where soil $\mathrm{pH}$ is above 7 or total alkalinity is above $50 \mathrm{mg} \mathrm{L}^{-1}$ (Boyd, 1995).

Aquaculture ponds are ordinarilly drained for harvest, bottoms are allowed to dry, and liming materials are applied. Lime is frequently blended with the bottom soil by tilling. In spite of the widespread use of lime, studies to compare the effectiveness of different methods of application have not been made. This study, conducted at a commercial fish farm, compares three methods of applying agricultural limestone to ponds, including: application over the pond water surface, application to the bottom of the dry pond, and application to the bottom of the dry pond followed by tilling.

\section{MATERIAL AND METHODS}

\section{Experimental Design}

The experiment was conducted in Itupeva District, São Paulo State $\left(23^{\circ} 11^{\prime} \mathrm{S}\right.$ and $\left.47^{\circ} 02^{\prime} \mathrm{W}\right)$. Soils in the area usually are of sandy clay or clayey texture of Ultisol and Oxisol orders. Pond bottoms had 300 - 400 $\mathrm{g} \mathrm{kg}^{-1}$ clay, 400 - $500 \mathrm{~g} \mathrm{~kg}^{-1}$ silt, and $100-200 \mathrm{~g} \mathrm{~kg}^{-1}$ sand. Water is supplied from a small, natural stream and all ponds are located on the stream's flood plain.

Trial was set up in $1,000-\mathrm{m}^{2}, 1.0-\mathrm{m}$ deep, rectangular ponds, stocked with 320,000 to 450,000 fingerling Nile tilapia. Feeds and fertilizers were applied according to the recommendations of the farm manager. The commercial fish feed contained 32\% crude protein, and each pond received 170 to $200 \mathrm{~kg}$ feed per month. The farmer did not keep records of fertilizer additions nor provided data on fish production. However, based on an assumed feed input of $2 \%$ body weight per day, standing crops of fish were estimated to be 2,800 to $3,200 \mathrm{~kg} \mathrm{ha}^{-1}$.

Nine ponds were made available, but it was not possible to initiate the entire experiment at once. One replication of each of the three treatments was installed in groups of three ponds on December 24, 2001, March 7, 2002, and May 18, 2002. Each group of ponds was managed for about 4 months before fish were harvested. The agricultural limestone dose was based on the lime requirement of the pond bottom soil and ranged from 4,000 and $5,000 \mathrm{~kg} \mathrm{ha}^{-1}$. The treatments were as follows: agricultural limestone applied over the water surface at the beginning of the crop; agricultural limestone spread uniformly over the bottom soil before filling ponds with water; agricultural limestone spread uniformly over the bottom soil and soil tilled to a depth of $10 \mathrm{~cm}$ with hand tools before filling ponds with water.

\section{Water and Soil Analyses}

Water samples were collected from ponds weekly and analyzed for total alkalinity and total hardness by acidimetry and EDTA (ethylenediaminetetraacetic acid) titration, respectively (Clesceri et al., 1998). Soil cores of $20-\mathrm{cm}$ length were collected from ten locations in each pond with a 5-cm diameter core tube before ponds were treated with agricultural limestone and at 1-month intervals for four months. The cores were cut into 2-cm long segments as described by (Munsiri et al., 1995). Soil samples were oven dried at $60^{\circ} \mathrm{C}$ in a mechanical convection oven and pulverized through a 40-mesh screen (0.425-mm openings). Soil pH was measured in 1:1 mixtures of dry soil and distilled water (Thunjai et al., 2001). The exchangeable acidity was measured by the change in $\mathrm{pH}$ caused by adding $5 \mathrm{~g}$ soil to $10 \mathrm{~mL}$ of a p-nitrophenol buffer solution (Adams \& Evans, 1962).

\section{Data Analysis}

The experiment was arranged as a split-split plot with lime application method (4) as main plots, soil depths (10) as sub-plots, and time (number of sampling dates: 10 for soil $\mathrm{pH}$ and exchangeable acidity, 10 for water alkalinity and hardness, and 2 for soil free calcium carbonate) as sub-sub-plots. Each plot/sub-plot/sub-subplot combination was replicated three times. A total of 12 ponds (four main plots and three replications) were used to conduct the experiment at each location. The combined analyses of data was realized to determine the average responses of treatment for all considered months, and also if these results were consistent for each month. The statistical model described by Steel \& Torrie (1980) was used.

\section{RESULTS AND DISCUSSION}

Immediately after filling with water, total alkalinity concentrations averaged from 25.6 to $33.2 \mathrm{mg} \mathrm{L}^{-1}$ in ponds of the three treatments. Total alkalinity remained above $25 \mathrm{mg} \mathrm{L}^{-1}$ after 2 weeks in all ponds and remained relatively stable throughout the study. Because there was little variation among sampling dates in total alkalinity, only the averages for the entire 4-month period were reported (Table 1). The total hardness concentrations averaged 26.0 to $36.2 \mathrm{mg} \mathrm{L}^{-1}$ when the ponds were filled. Concentrations increased above $24 \mathrm{mg} \mathrm{L}^{-1}$ within 2 weeks, and as with total alkalinity, remained fairly stable. Averages for total hardness during the 4-month period also are provided (Table 1). 
Table 1 - Average concentrations of total alkalinity (TA) and total hardness (TH) in ponds that were treated with agricultural limestone by three methods.

\begin{tabular}{|c|c|c|c|c|}
\hline \multirow[b]{2}{*}{ Treatment } & \multicolumn{2}{|c|}{ Initial } & \multicolumn{2}{|c|}{ Average for study period } \\
\hline & TA & TH & TA & $\mathrm{TH}$ \\
\hline & - - & ---- $\mathrm{mg} \mathrm{L}^{-1} \mathrm{a}$ & $\mathrm{CaCO}_{3}-\cdots$ & - \\
\hline Applied to water & $25.6 \pm 2.7$ & $26.0 \pm 7.7$ & $27.2 \pm 1.6$ & $24.4 \pm 1.8$ \\
\hline Applied to soil & $29.5 \pm 7.1$ & $31.7 \pm 13.9$ & $32.0 \pm 4.3$ & $29.6 \pm 4.6$ \\
\hline Applied to soil and tilled & $33.2 \pm 5.9$ & $36.2 \pm 11.7$ & $28.3 \pm 4.2$ & $25.5 \pm 3.7$ \\
\hline
\end{tabular}

Total alkalinity and total hardness presented similar variation in the three liming treatments. No differences were found between the treatments for total alkalinity $(P>0.35)$ and total hardness $(P>0.47)$. There were no interactions between liming treatments and time after lime application for total alkalinity $(P>0.71)$ and total hardness $(P>0.78)$.

The effects of five time intervals were studied and they showed differences only for total alkalinity $(P>0.001)$. The time intervals started one month after lime application corresponding to the first interval, and every three weeks corresponded to the subsequent intervals until the end of the experiment. The data showed a significant increase in total alkalinity after 10 weeks of lime application, and this was not affected by the lime application method (Duncan test, $\alpha=0.05$, SEM = 20.81) (Table 2). Treatment with agricultural limestone increased concentrations of total alkalinity and total hardness $(P<0.05)$ over the experimental period, but the method of applying agricultural limestone did not influence the average concentrations of the two variables.

The exchangeable acidity of the soil samples was quite low and often no more than 1 or 2 meq $100 \mathrm{~g}^{-1}$. Such low exchangeable acidity values for soils with low $\mathrm{pH}$ reveals that the soil had low cation exchange capacity (Boyd, 1995). The low exchangeable acidity concentrations also were difficult to measure, because an expandedscale $\mathrm{pH}$ meter capable of $0.01 \mathrm{pH}$ accuracy was not available.

The coefficient of variation related to exchangeable acidity of pond bottom soils, after square root transformation was $21.99 \%$, and no differences were observed among treatments $(P>0.65)$. However, differences in exchangeable acidity between depths were observed $(P<0.0001)$, mostly occurring within $0-10 \mathrm{~cm}$. There were no two-way and three-way interactions, with exception of the interaction between treatment and time $(P<0.0005)$. Therefore, the effects of each treatment were evaluated over time, and were highly significant $(0.0001<P<0.0021)$. For the treatment where agricultural lime was applied over pond water surface, exchangeable acidity was higher three months after application with differences in relation to remaining months
Table 2 - Average concentrations of total alkalinity over all the experimental period in ponds that were treated with agricultural limestone by three methods $(\mathrm{N}=12)$.

\begin{tabular}{lc}
\hline Time & Average \\
\hline weeks & $\mathrm{mg} \mathrm{L}^{-1}$ as equivalent $\mathrm{CaCO}_{3}$ \\
17 & $27.01 \mathrm{bc}$ \\
13 & $24.10 \mathrm{c}$ \\
10 & $32.47 \mathrm{a}$ \\
7 & $30.40 \mathrm{ab}$ \\
4 & $27.52 \mathrm{bc}$ \\
\hline
\end{tabular}

Means with the same letter are not different by Duncan's test $(P<0.05)$.

(Duncan test, $\alpha=0.05$ ). This could be related to a reduction on the action of agricultural lime over pond bottom soil. There were also differences in exchangeable acidity one month after application of agricultural lime over the soil surface in comparison to the other months (Duncan test, $\alpha=0.05$ ). For the treatment where agricultural lime was incorporated into the soil by tilling, the same trend was observed.

Data regarding mud $\mathrm{pH}$ of pond bottom soil presented a coefficient of variation of $4.75 \%$ among samples and indicates that the soils at the fish farm did not present a large variation in composition. No differences were observed among treatments during the experiment $(P>0.12)$, but differences in mud $\mathrm{pH}$ were observed among soil depths $(P<0.0001)$ (Table 3$)$. The mud $\mathrm{pH}$ of the superficial layer $(0-2 \mathrm{~cm})$ was higher in comparison to the deeper layers. Thus, liming effects were most effective in the first layer and effectiveness decreased with depth. There were also differences on mud $\mathrm{pH}$ values during the experimental period $(P<0.0014)$ (Table 4).

Data regarding dry $\mathrm{pH}$ (mixture 1:1 soil distilled water) of pond bottom soil, presented a coefficient of variation of $4.65 \%$. All double interactions, with exception of the interaction between treatment versus depth were not significant $(P>0.0001)$. Therefore, the results of each treatment according to the different depths were evaluated. The triple interaction was also not significant, and all the treatment effects over soil depth were signifi- 
Table 3 - Average soil mud $\mathrm{pH}$ in pond bottoms at different depths following application of agricultural limestone during all the experimental period $(\mathrm{N}=48)$.

\begin{tabular}{lc}
\hline Soil depth & Average \\
\hline $\mathrm{cm}$ & $\mathrm{pH}$ \\
$0-2$ & $6.71 \mathrm{a}$ \\
$2-4$ & $6.59 \mathrm{~b}$ \\
$4-6$ & $6.33 \mathrm{c}$ \\
\hline $6-8$ & $6.03 \mathrm{~d}$ \\
\hline $8-10$ & $5.79 \mathrm{e}$ \\
$10-12$ & $5.56 \mathrm{f}$ \\
$12-14$ & $5.43 \mathrm{~g}$ \\
$14-16$ & $5.36 \mathrm{~g}$ \\
$16-18$ & $5.22 \mathrm{~h}$ \\
$18-20$ & $5.13 \mathrm{~h}$ \\
\hline
\end{tabular}

Means with the same letter are not different by Duncan's test $(P<0.05)$.

Table 4 - Average soil mud pH in pond bottoms at different times following application of agricultural limestone during all the experimental period $(\mathrm{N}=120)$.

\begin{tabular}{lc}
\hline Time & Average \\
\hline Months & $\mathrm{pH}$ \\
5 & $5.75 \mathrm{~b}$ \\
4 & $5.87 \mathrm{a}$ \\
3 & $5.86 \mathrm{a}$ \\
2 & $5.78 \mathrm{~b}$ \\
\hline $\begin{array}{l}\text { Means with the same letter are not different by Duncan's test } \\
(P<0.05) .\end{array}$
\end{tabular}

cant $(P<0.0001)$. Regarding the treatment where liming material was applied directly over the pond water surface (Table 5), dry $\mathrm{pH}$ on the first layer $(0-2 \mathrm{~cm})$ differed in relation to the other treatments (Duncan test, $\alpha=0.05$ ). There also was a trend of decreasing $\mathrm{pH}$ with increasing depth (Table 5). There was also difference in $\mathrm{pH}$ related to time $(P<0.0005)$ and four months after lime application, a higher average of dry $\mathrm{pH}$ was observed in comparison to the other times (Table 6).

Several features of the data are listed below:

1. All ponds initially had soil $\mathrm{pH}$ below 6 .

2. Treatment with agricultural limestone increased soil $\mathrm{pH}$ above 6 in the 0-6 cm layer for all samples of all treat ments, and in most samples from the 6-8 cm layer.

3. Treatment with agricultural limestone did not increase $\mathrm{pH}$ above 6 in soil below $8 \mathrm{~cm}$ depth.

4. Soil $\mathrm{pH}$ in samples taken before agricultural limestone was applied tended to decrease with increasing soil depth. The same trend existed after agricultural lime stone was applied.

Agricultural limestone caused an increase in soil $\mathrm{pH}$ within the upper 8-cm layer of soil, with the greatest increase being in the $0-4 \mathrm{~cm}$ layer $(P<0.05)$ (Figure 1 ). Considering all data, there were no differences among treatments on any dates $(P>0.05)$ for $\mathrm{pH}$ values when comparisons were made among the same depth layers. The reaction of agricultural limestone occurred quickly, and there was no difference in $\mathrm{pH}$ after the first month among treatments when a single soil layer was considered (Figure 2). The increase in $\mathrm{pH}$ over initial $\mathrm{pH}$ was greatest in the $0-2 \mathrm{~cm}$ layer and became progressively less with greater soil depth.

Agricultural limestone reacts quickly to increase the total alkalinity and total hardness of pond water. The total alkalinity and total hardness concentrations after lim-

Table 5 - Average soil dry pH of pond bottoms at different depths, after agricultural limestone application $(\mathrm{N}=12)$.

\begin{tabular}{|c|c|c|c|c|}
\hline \multirow[b]{2}{*}{ Soil depth } & \multicolumn{4}{|c|}{ Limestone application } \\
\hline & Over pond water surface & No liming & Pond bottom soil & Tilled pond bottom soil \\
\hline $\mathrm{cm}$ & - - - - & 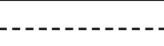 & - & 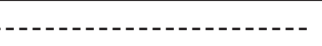 \\
\hline $0-2$ & $6.63 \mathrm{a}$ & $6.31 \mathrm{a}$ & $7.07 \mathrm{a}$ & $6.60 \mathrm{a}$ \\
\hline $2-4$ & $6.15 \mathrm{~b}$ & $6.13 \mathrm{a}$ & $6.60 \mathrm{~b}$ & $6.59 \mathrm{a}$ \\
\hline $4-6$ & $5.89 \mathrm{c}$ & $5.81 \mathrm{~b}$ & $6.08 \mathrm{c}$ & $6.04 \mathrm{~b}$ \\
\hline $6-8$ & $5.78 \mathrm{~cd}$ & $5.66 \mathrm{bc}$ & $5.77 \mathrm{~d}$ & $5.81 \mathrm{c}$ \\
\hline $8-10$ & $5.69 \mathrm{cde}$ & $5.52 \mathrm{~cd}$ & $5.51 \mathrm{e}$ & $5.70 \mathrm{~cd}$ \\
\hline $10-12$ & $5.58 \mathrm{def}$ & $5.46 \mathrm{cde}$ & $5.47 \mathrm{e}$ & $5.61 \mathrm{cde}$ \\
\hline $12-14$ & $5.58 \mathrm{def}$ & $5.37 \mathrm{de}$ & $5.41 \mathrm{e}$ & $5.54 \mathrm{def}$ \\
\hline $14-16$ & 5.45 ef & $5.37 \mathrm{de}$ & $5.38 \mathrm{e}$ & $5.41 \mathrm{ef}$ \\
\hline $16-18$ & $5.43 \mathrm{ef}$ & $5.29 \mathrm{de}$ & $5.34 \mathrm{e}$ & $5.35 \mathrm{fg}$ \\
\hline $18-20$ & $5.36 \mathrm{f}$ & $5.22 \mathrm{e}$ & $5.32 \mathrm{e}$ & $5.15 \mathrm{~g}$ \\
\hline
\end{tabular}

Means followed by the same letter do not differ by Duncan's test $(\alpha=0.05)$. 
Table 6 - Average soil dry $\mathrm{pH}$ in pond bottoms at different times during all the experimental period $(\mathrm{N}=120)$.

\begin{tabular}{lc}
\hline Time & Average \\
\hline weeks & $\mathrm{pH}$ \\
5 & $5.82 \mathrm{a}$ \\
4 & $5.70 \mathrm{~b}$ \\
3 & $5.74 \mathrm{~b}$ \\
2 & $5.68 \mathrm{~b}$ \\
\hline
\end{tabular}

Means with the same letter are not different by Duncan's test $(P<0.05)$.
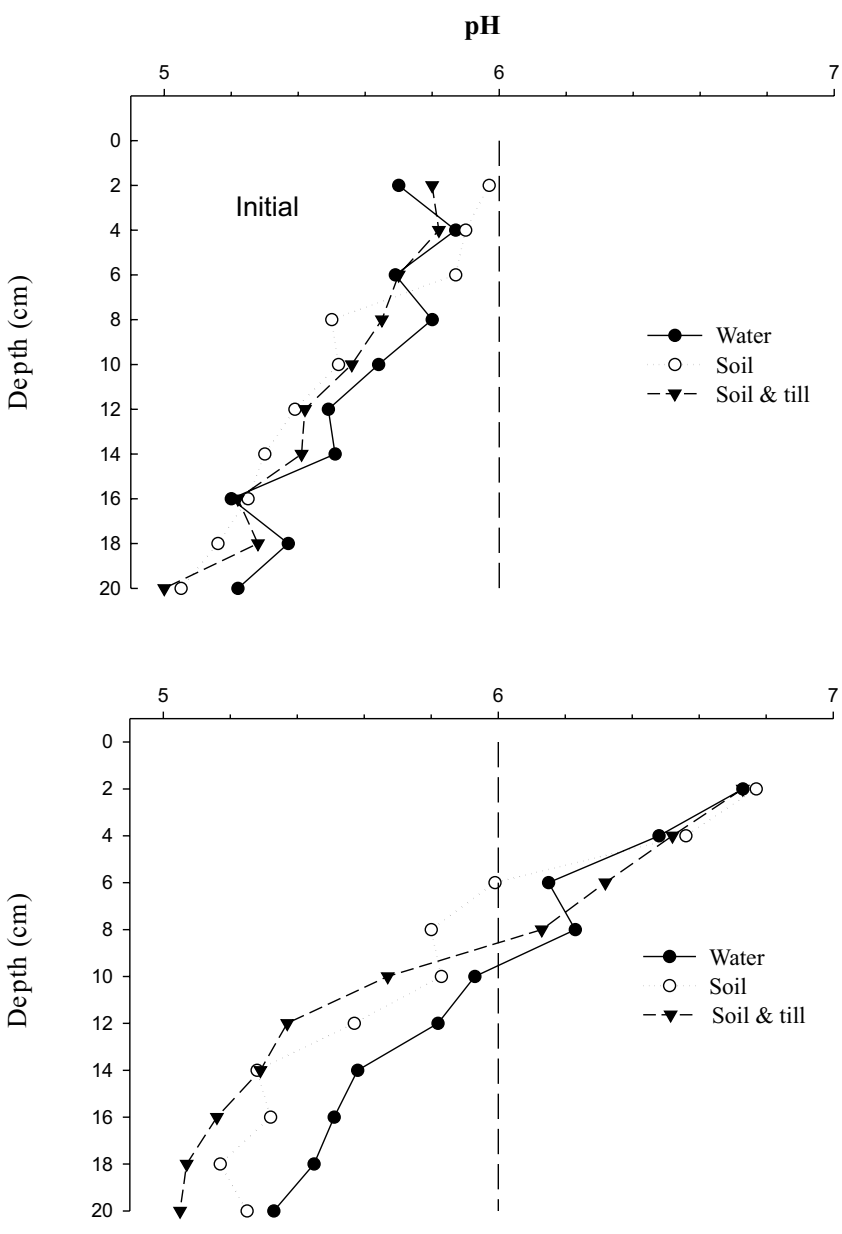

Figure 1 - Average soil $\mathrm{pH}$ at different depths in the bottoms of fish ponds before treatment (initial) and 4 months after treatment (final) with agricultural limestone. The agricultural limestone application methods were as follows: water - applied over water surface; soil - applied on the bottom of empty pond; soil and till - applied over the bottom of empty pond after which the bottom was tilled.

ing averaged 24.4 and $32.0 \mathrm{mg} \mathrm{L}^{-1}$. Agricultural limestone is sparingly soluble, and the equilibrium concentration between solid calcium carbonate, water, and the normal atmospheric carbon dioxide level is about $57 \mathrm{mg} \mathrm{L}^{-1}$ (Stumm \& Morgan, 1996). The solubility of agricultural limestone increases in waters where the dissolved carbon dioxide concentration is higher than that expected from equilibrium with normal atmospheric carbon dioxide (Hutchinson, 1957). In ponds, decomposition of soil organic matter by microorganisms and respiration of other aquatic organisms increases carbon dioxide concentration, and the total alkalinity and total hardness may become quite high.

The depth of reaction of liming material into bottom soil is small in clayey soils in comparison to sandy soils. The upper $5 \mathrm{~cm}$ of pond soil has the greatest influence on pond water quality and shrimp and fish production (Boyd, 1995). All three methods of application resulted in an increase in $\mathrm{pH}$ in this layer. These results and the increases in total alkalinity and total hardness concentrations confirm that all three methods of application were effective. The rate and the depth of reaction were not related to the method of application. The maximum benefit of agricultural limestone was achieved in one to two months.

Ponds can be effectively limed by spreading agricultural limestone over water surfaces. Of course, if ponds are drained after each crop, it is easier to spread agricultural limestone over the pond bottom than to spread it over the water surface. Tilling pond bottom after applying agricultural limestone did not promote the reaction of the liming material with soil. Although tilling is beneficial for improving dry out and decomposition of organic residues in clayey soils (Boyd, 1995), ponds with sandy or loamy soils usually dry out easily and tilling to lessen soil organic matter concentration is only necessary after several crops.

\section{CONCLUSIONS}

Liming is a common practice in pond aquaculture, and greater efficiency in the use of liming materials will benefit fish and shrimp producers. Ponds can be effectively limed by applying liming materials over the water surface. It is not necessary to drain ponds and lime the bottoms. Pond effluents can pollute receiving waters, so aquaculture methods that allow ponds to be operated for several years without draining are highly desirable. Evidence was provided that undrained ponds can be prevented from becoming acidic through applying agricultural limestone over the water surface. Agricultural limestone reacts quickly and can increase concentrations of total alkalinity and total hardness within two weeks and soil $\mathrm{pH}$ within one or two months. Thus, liming does not have to be done several months before benefits are achieved. Finally, agricultural limestone does not have to be tilled into the soil. This can lead to savings in labor costs. 

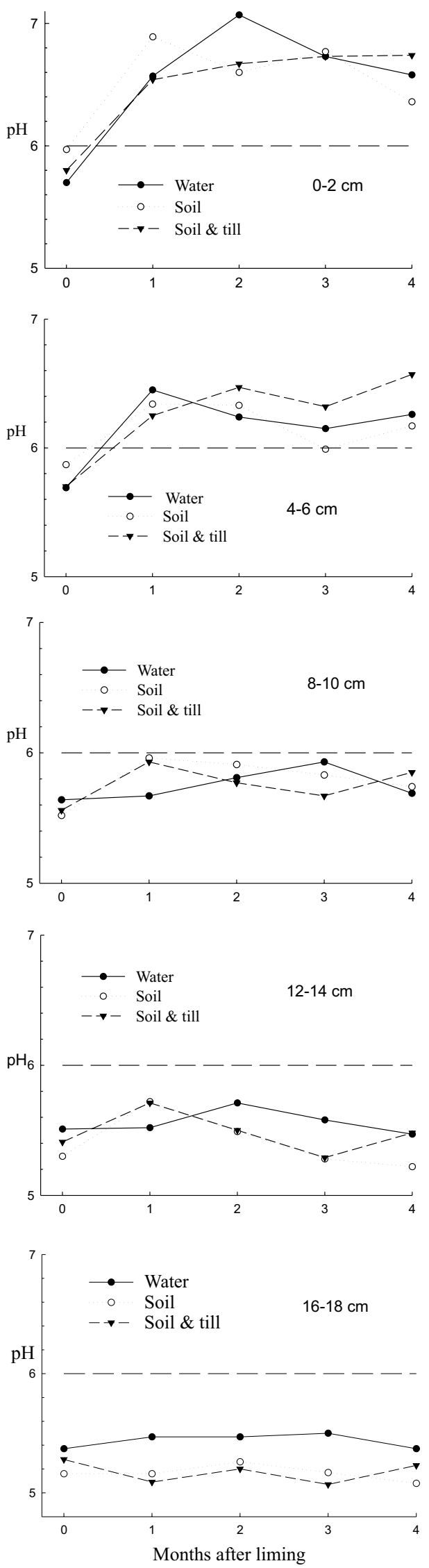
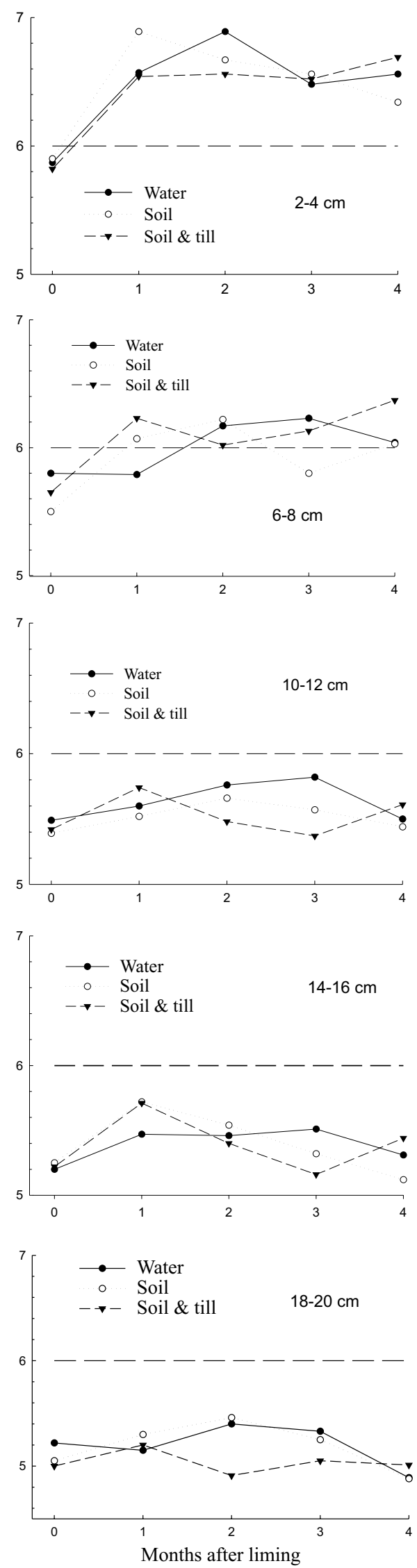

Figure 2 - Average soil pH in different depth layers in the bottoms of fish ponds before treatment and at monthly intervals after treatment with agricultural limestone. The agricultural limestone application methods were as follows: water - applied over water surface; soil applied on the bottom of empty pond; soil and till - applied over the bottom of empty pond after which the bottom was tilled. 


\section{ACKNOWLEDGMENTS}

To Mr. Valdir Donizete Betelli, owner of the Santa Barbara Fish Farm in Itupeva, SP, for allowing us to use his ponds and providing valuable assistance. To PD/A CRSP - Pond Dynamics Aquaculture - Collaborative Research Support Program, for providing the necessary financial support through the Work Plan No. 10, Grant No. 1282 to allow the development of this study.

\section{REFERENCES}

ADAMS, F.; EVANS, C.E. A rapid method for measuring lime requirement of red-yellow podzolic soils. Soil Science Society of America Proceedings, v.26, p.355-357, 1962.

BOYD, C.E. Liming fish ponds. Journal of Soil and Water Conservation, v.37, p.86-88, 1982.

BOYD, C.E. Bottom soils, sediment, and pond aquaculture. New York: Chapman and Hall, 1995. 348p.

BOYD, C.E.; TUCKER, C.S. Pond aquaculture water quality management. Boston: Kluwer Academic Publishers, 1998. 700p.
CLESCERI, L.S.; GREENBERG, A.E.; EATON, A.D. Standard methods for the examination of water and wastewater. 20.ed. Washington: APHA, 1998.

HUTCHINSON, G.E. A treatise on limnology. New York: John Wiley and Sons, 1957. v.1: Geography, physics, and chemistry.

MUNSIRI, P.; BOYD, C.E.; HAJEK, B.J. Physical and chemical characteristics of bottom soil profiles on ponds at Auburn, Alabama, USA, and a proposed method for describing pond soil horizons. Journal of the World Aquaculture Society, v.26, p.346-377, 1995.

STEEL, R.G.D.; TORRIE, J.H. Principles and procedures of statistics. 2.ed. New York: Mc Graw Hill, 1980. 633p.

STUMM, W.; MORGAN, J.J. Aquatic chemistry. New York: John Wiley and Sons, 1996. 1022p.

THOMASTON, W.W.; ZELLER, H.D. Results of a six-year investigation of chemical soil and water analysis and lime treatment in Georgia fish ponds. In: Annual Conference of the South Eastern Association of Game and Fish Commissioners, 1961. v.15, p.236-245.

THUNJAI, T.; BOYD, C.E.; DUBE, K. Pond soil pH measurement. Journal of the World Aquaculture Society, v.32, p.141-152, 2001.

Received October 10, 2003

Accepted August 18, 2004 